\title{
Psychological Contract Management Strategy of Knowledge Workers in Boundaryless Career Era
}

\author{
Yunfei $\mathrm{Xu}^{1, *}$ Han Wang ${ }^{2}$ Yong Zhang ${ }^{3}$ Yan Chang $^{4}$ \\ 1,2,3,4 State Grid Energy Research Institute Co. LTD,Changping, 102209, Beijing, China \\ *Corresponding author. Email: xuyunfei@sgeri.sgcc.com.cn
}

\begin{abstract}
In boundaryless career era, the organization has become increasingly small, agile and rapid, showing the characteristics of informationization, decentralization, virtualization, flattening and miniaturization. The psychological contract between employees and the organization has changed from "relationship type" to "transaction type". The purpose of this paper is to explore the new changes of the psychological contract of knowledge workers and the corresponding management strategies under the background of boundaryless career era. In the boundaryless career era, the psychological contract characterized by employee loyalty which is in exchange for employment security is gradually replaced by the new psychological contract characterized by performance which is in exchange for employment ability. Therefore, enterprises are required to establish a learning organization to enhance the external employability of knowledge workers through career guidance, and strengthen the practice of human resource management to develop and maintain this new psychological contract, so as to realize the long-term sustainable development of the organization.
\end{abstract}

Keywords: Boundaryless Career, Knowledge Workers, Psychological Contract

\section{INTRODUCTION}

Since the 1990s, with the rise of economic globalization and knowledge economy, the competition among enterprises has become increasingly fierce, and the internal and external environment faced by enterprises has changed greatly, thus bringing changes in organizational structure and form. In order to maintain organizational flexibility and resiliency, employees must switch between different positions and roles within the organization and even move between different organizations. Their career has broken through the traditional organizational boundaries and entered the era of boundaryless career. The emergence of boundaryless career era puts forward higher requirements for employees' employment concept and employment ability [1]. "Knowledge workers, as talents mastering science and technology, are the focus of competition in the current and future era". Under the background of the current economic and social transformation in China, the market and organizational environment on which the psychological contract between employees and the organization has undergone significant changes, requiring employees and enterprises to constantly change their ideas and attach importance to the new changes of psychological contract. Therefore, it is of great theoretical and practical significance to discuss the change and management of psychological contract of knowledge workers in the era of boundaryless career [2].

\section{THE CHARACTERISTICS OF BOUNDARYLESS CAREER}

The concept of boundaryless career originated in the 1990s and was first proposed in 1994 by Defillppi and Arthur, who defined boundaryless career as "a series of employment opportunities that transcend the boundaries of a single organization". Boundaryless refers to the boundary state beyond the boundary of job role, occupation, organization and employment relationship. Arthur and Rousseau (1996) pointed out that, compared with traditional career, boundaryless career emphasizes the flexibility of employees' mobility across different employers or organizational boundaries and employability which is in exchange for performance [3]. It has the following characteristics: employees move across different employers and organizational boundaries. Employees need to gain recognition and employability outside the employer and organization. Career development depends on external networks and information. Traditional organizational boundaries were broken down. The tendency to forgo job opportunities for 
personal or family reasons and the tendency for employees to perceive boundaryless professionalism. The comparison between traditional and boundaryless career is shown in Table 1.

Table 1 Comparison of traditional career and boundaryless career

\begin{tabular}{l|l|l}
\hline Dimension & Traditional career & Boundaryless career \\
\hline $\begin{array}{l}\text { Employment } \\
\text { relationship }\end{array}$ & $\begin{array}{l}\text { trade job security for } \\
\text { loyalty }\end{array}$ & $\begin{array}{l}\text { trade employability for } \\
\text { performance and flexibility }\end{array}$ \\
\hline $\begin{array}{l}\text { Occupational } \\
\text { boundaries }\end{array}$ & one or two organizations & multiple organizations \\
\hline Required skills & organization-specific & transferable and portable \\
\hline Training & $\begin{array}{l}\text { formal scheme and } \\
\text { program }\end{array}$ & on-the-job learning \\
\hline $\begin{array}{l}\text { Occupational } \\
\text { management } \\
\text { responsibility }\end{array}$ & organization & individual \\
\hline Career history & related to age & related to learning \\
\hline Employment contract & $\begin{array}{l}\text { fixed employment } \\
\text { contract }\end{array}$ & $\begin{array}{l}\text { flexible employment } \\
\text { contract }\end{array}$ \\
\hline Psychological contract & $\begin{array}{l}\text { relational psychological } \\
\text { contract }\end{array}$ & $\begin{array}{l}\text { transactional } \\
\text { psychological contract }\end{array}$ \\
\hline Career success & $\begin{array}{l}\text { Objective and external } \\
\text { indicators: } \\
\text { promotion, status }\end{array}$ & $\begin{array}{l}\text { Subjective feeling: } \\
\text { psychologically } \\
\text { meaningful of work }\end{array}$ \\
\hline
\end{tabular}

Source: Sullivan, Sherry E. The Changing nature of careers: a review and research agenda. Journal of management , 1999, 25(3):457-484.

In boundaryless career era, career management background has changed. First, the market environment has become unpredictable. Second, the digital revolution requires the organization to become smaller, more agile and faster when dealing with the market environment. By streamlining decision-making levels and removing barriers between functional units, new "boundaryless" organizations are produced. Third, the traditional employment relationship (with long-term stability) is gradually disintegrating, and the new employment relationship (highly flexible and short-term) is becoming increasingly popular. Fourth, the psychological contract between employees and the organization has changed from "relationship type" to "transaction type", and employees must pursue employability by improving their skills. Fifth, the organization is characterized by informationization, decentralization, virtualization, flattening and miniaturization, and its internal environment is becoming more and more unstable, and employees' "sense of security" is obviously reduced. The career is becoming more and more turbulent, and the path of continuous upward promotion along the organizational ladder is disappearing. Sixth, the position in the organization is weakened, and the work becomes a task that starts with a project and ends with a product. For the organization, this way of working is flexible, efficient and low-cost, while for individuals, it puts forward higher requirements for working ability and adaptability.

Peter Drucker pointed out that since employees have acquired the tools of production through their knowledge, their relationship with the organization has changed fundamentally. Compared with other professionals, knowledge workers attach much more importance to challenging work that promotes their continuous development, and the marginal value of financial incentives has been relegated to a relatively minor position compared with growth, autonomy and achievement. These characteristics of knowledge workers affect the content and structure of their psychological contract. In an era of boundaryless career, knowledge workers will have more opportunities and challenges. Therefore, the research on the psychological contract of knowledge workers is helpful for enterprises to motivate employees from a deeper level, establish a harmonious and win-win sharing relationship between enterprises and employees, and help enterprises to attract and retain talents.

\section{PSYCHOLOGICAL CONTRACT FOR KNOWLEDGE WORKERS IN THE ERA OF BOUNDARYLESS CAREER}

Boundaryless career breaks the assumption that the organization can provide lifetime employment to ensure employees' employment security, highlighting the instability and variability of career development under the new situation, which leads to changes in employees' psychological contract, organizational commitment and loyalty. Herriot and Pemberton (1995) propose that career can be viewed as a series of negotiations based on psychological contract among employees. In the boundaryless career era, the original stable psychological contract between employees and the organization is broken, which changes from long-term relational psychological contract to short-term and temporary transactional psychological contract.

The change of psychological contract is a great challenge to employees' career development and organizational performance. Psychological contract is a very complex psychological structure, which contains a wide range of contents, such as compensation and benefits, training and promotion, leadership support, working atmosphere, etc. These contents can be roughly divided into two dimensions: transactional and relational. Transactional contracts are contractual relationship based on economic exchange, in which the organization explicitly or implicitly promises to provide specific, short-term monetary rewards and rewards according to the tasks performed by employees. Such as high wages, seasonal employment and so on. Relational contract, on the other hand, is based on social emotional exchange and emphasizes the interaction between employees and the organization, including long-term job security, long-term career development, training and promotion opportunities, etc [4].

In the boundaryless career era, the psychological contract between the employee and the organization changes from relational to transactional. Based on the analysis of the characteristics of the era of psychological contract, Hiltrop (1995) pointed out that psychological contract has changed a lot in terms of focus, form of contract, organizational responsibility, employee 
responsibility, career management, etc., reflecting new characteristics [5]. See Table 2.

Table 2 Comparison between traditional psychological contract and new Era psychological contract

\begin{tabular}{|c|c|c|}
\hline Characteristics & $\begin{array}{l}\text { Traditional Psychological } \\
\text { Contract }\end{array}$ & $\begin{array}{l}\text { New Era Psychological } \\
\text { Contract }\end{array}$ \\
\hline Focus & $\begin{array}{l}\text { job security, job continuity } \\
\text { and loyalty }\end{array}$ & employability and tradability \\
\hline Contract form & $\begin{array}{l}\text { Stability, } \\
\text { predictability }\end{array}$ & $\begin{array}{l}\text { Flexible, unstructured and } \\
\text { based on extensive } \\
\text { consultations }\end{array}$ \\
\hline Contract basis & $\begin{array}{l}\text { Practice, equity, social and } \\
\text { economic status }\end{array}$ & $\begin{array}{l}\text { Market-driven, transactional, } \\
\text { skills and capabilities, added } \\
\text { value }\end{array}$ \\
\hline $\begin{array}{l}\text { Organizational } \\
\text { responsibility }\end{array}$ & $\begin{array}{l}\text { Job security, training, career } \\
\text { development }\end{array}$ & 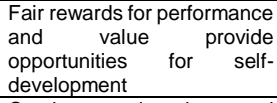 \\
\hline $\begin{array}{l}\text { employee } \\
\text { responsibility }\end{array}$ & $\begin{array}{lr}\begin{array}{l}\text { Loyalty, } \\
\text { authority, }\end{array} & \text { compliance } \\
\text { standards } & \text { performance } \\
\end{array}$ & 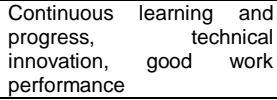 \\
\hline $\begin{array}{l}\text { Career } \\
\text { management }\end{array}$ & $\begin{array}{l}\text { Organizational responsibility, } \\
\text { through the human resources } \\
\text { department to plan and } \\
\text { promote the internal spiral of } \\
\text { career development }\end{array}$ & $\begin{array}{l}\text { Employee responsibility, } \\
\text { through personal retraining } \\
\text { and relearning to achieve the } \\
\text { external spiral of career } \\
\text { development }\end{array}$ \\
\hline
\end{tabular}

In the boundaryless career era, it is necessary for employees and the organization to share the responsibility of career management, so as to maintain and improve the employability of each employee inside and outside the organization. The responsibility of the organization is to provide employees with an open, autonomous environment and opportunities to evaluate and develop their work capabilities. The responsibility of employees is to constantly learn, improve their job skills and performance and manage their careers.

\section{PSYCHOLOGICAL CONTRACT MANAGEMENT OF KNOWLEDGE WORKERS IN THE ERA OF BOUNDARYLESS CAREER}

As an "implicit and unwritten contract", psychological contract would affect employees' job performance, organizational commitment, organizational citizenship behavior and loyalty. In the boundaryless career era, the internal and external environment faced by the organization will be more complex, and both employees and the organization need stronger adaptability to reach, maintain and promote the development of psychological contracts.

\subsection{To Change Career Orientation into Career Guidance, and Guide Knowledge Workers to Strengthen their Career Management}

In the previous career development process, enterprises played a dominant role in determining the career path of employees, such as job allocation, promotion, training and further study opportunities, etc. Employees' career development largely depended on the appointment and allocation of the organization. However, in the era of boundaryless career, as knowledge workers have higher and stronger employability, especially those with portable and transferable ability, enterprises should shift from leading to mentoring, guide knowledge workers to understand their interests and career needs, and conduct self-career management. On the one hand, to communicate regularly and adequately with knowledge workers, understand their needs and expectations, find out their vocational interest, career development plans and career success criteria, etc., pay attention to knowledge workers' subjective feelings and the change of mental state, meaning including job satisfaction, work engagement, work-life balance and so on. On the other hand, enterprises need to provide training and learning opportunities for knowledge workers, provide relevant information on career development, and provide specific guidance and help for the improvement of knowledge workers' performance level and career development.

\subsection{To Build a Learning Organization to Enhance the Employability of Knowledge Workers}

In the boundaryless career era, knowledge workers can only win competitive advantage in the complex and changeable environment by constantly learning and improving their learning ability and efficiency. Employability is the common interest basis for the establishment of new employment contract relationship between employers and employees. Therefore, enterprises should take the construction of learning organization as the goal, create a cultural atmosphere of continuous learning and continuous innovation, guide knowledge workers to continue learning, and cultivate their learning concept and learning ability. At the same time, enterprises should continuously provide opportunities for personal development and new knowledge and skills, promote knowledge workers to constantly update and enrich their knowledge and skills reserve, cultivate and enhance their external employability to cope with the increasingly fierce competition.

\subsection{To Attach Importance to Human Resource Management Practice, establish and Maintain a Good Psychological Contract}

Compared with traditional career, boundaryless career takes on new characteristics in employment relationship, occupational boundaries, required skills, training and management responsibility, etc. Employees' career success evaluation criteria, career management subjects, and requirements for employees all change significantly, especially for knowledge employees, their psychological contract has completely different performance under the background of boundaryless career. How to manage the psychological contract of knowledge workers is of great significance to adapt to the development requirements of boundaryless career era [6]. This paper proposes to 
manage the psychological contract of knowledge workers in the background of boundaryless career era from three aspects: the first is to change career orientation into career guidance and guide knowledge workers to strengthen their career management. The second is to build a learning organization to enhance the employability of knowledge workers. The third is to attach importance to human resource management practice, establish and maintain a good psychological contract.

\section{CONCLUSION}

Boundaryless career presents brand-new features in employment relationship, occupational boundaries, required skills, training, occupational management responsibility, etc. The evaluation criteria of employees' career success, the main body of career management, and the requirements for employees have changed significantly. The promotion opportunities of employees are greatly reduced. There is no longer a traditional longterm employment form between the organization and employees, but a short-term employment form. Employees are changing between different organizations in order to seek better development. These changing factors put forward higher requirements for organizational management and personal career development of employees. In order to adapt to the new changes and requirements in the era of boundaryless career, enterprises need to attach importance to the management of knowledge workers' psychological contracts, actively take various measures to maintain their psychological contracts, and promote the establishment and maintenance of harmonious employee-organization relationship.

\section{ACKNOWLEDGMENTS}

This research was supported by the State Grid Corporation of China Science and Technology Project "Research on talent supply and demand analysis model and supply strategy suitable for company strategy".

\section{REFERENCES}

[1] S.E. Sullivan. The Changing nature of careers: a review and research agenda. Journal of management, 1999, 25(3):457-484.

[2] M.B. Arthur. The Boundaryless career: A new perspective for organizational inquiry. Journal of organizational Behavior, 1994, 15: 295- 306.

[3] M. B. Arthur, D. M. Rousseau. The boundaryless career as a new employment principle. In: M. G. Arthur\& D. M. Rousseau (Eds.). The boundaryless career. New York: Oxford University Press,1996:320
[4] Y. Li, D.J. Guo. Latent credit: psychological contract in organization $[\mathrm{J}]$. Advances in psychological science, 2002, (01).

[5] Z.W. Guo, B.I.J.M van de Heden. Employability in boundaryless career era: a new psychological contract [J]. psychological science, 2006,02:485486.

[6] C.Y. Jiang, S.M. Zhao. Characteristics, causes and countermeasures of knowledge worker mobility [J]. China Soft Science, 2001, (2): 86-89. 